\title{
Participatory evaluation and promotion of cereals and grain legumes for enhancing food security at Bajura district, Nepal

\author{
RK Neupane ${ }^{*}$ BP Mahato, ${ }^{* *}$ R Darai**, and B Hamal ${ }^{* *}$
}

\begin{abstract}
Participatory varietal selection (PVS) trials in maize, wheat, finger millet, buckwheat, pigeon pea and field pea, mixed cropping legumes with maize were implemented and farmer-preferred varieties of those crops disseminated in Barabish VDC (900-1600 m) of Bajura district during 2007/08 to 2009/10 with a view to enhance the local level food security. Results from PVS trials showed that maize variety Deuti produced the highest mean grain yields of $3625 \mathrm{~kg}$ /ha which was $25 \%$ higher than the local variety, wheat variety WK-1204 was the highest yielder ( $3901 \mathrm{~kg} / \mathrm{ha})$, with $48 \%$ more yields than the popular and check variety RR-21. Fingermillet variety KK -1 was the highest yielder $(2459 \mathrm{~kg} / \mathrm{ha})$ in midhills, whereas ACC \# 2827-1, NF1703-34, and performed better in high hills. This variety showed wider adaptation both in the mid and high hills. Sweet buckwheat genotype IR-13 was most preferred by farmers. For bitter buckwheat, genotypes ACC \#- 2223-1 (4813 kg/ha), Sample \# 8 (2333 kg/ha) and ACC \# -2227-1 (1354 kg/ha) were high yielding. Field pea variety Sikkime produced the highest fresh pod yield of $4185 \mathrm{~kg} / \mathrm{ha}$ and was superior to Kalaam Local. Seed yields of medium duration pigeonpea variety Rampur Rahar-1 evaluated for the first time in the locality, ranged between $250-1500 \mathrm{Kg} / \mathrm{ha}$. Extra short duration variety of pigeonpea suitable for growing in pigeonpea-wheat rotation in rainfed uplands has been selected by farmers. The economic benefit of intercropping groundnut with maize was higher than intercropping pigeonpea or soybean, due to higher selling price of groundnut. On-farm seed saving and seed procurement of selected varieties had been initiated to ensure adequate seed supply at the local level. More than $1829 \mathrm{~kg}$ seed of wheat variety WK-1204 was produced and $40 \%$ of it was used as seed in 2010 winter season. A total of 328 farmers comprising $28 \%$ females and $72 \%$ males were benefited through participation in crop and seed production trainings organized at the villages. Upscaling of selected varieties / technologies has been suggested.
\end{abstract}

Key words: Pigeonpea, intercropping, PVS, cereals, Bajura

\section{Introduction}

Food insecurity in the western hills is a chronic problem. The food self sufficiency ratio (SSR) of Bajura district is only 32 (Dahal et al; 2010). In spite of the recommendation of a

\footnotetext{
* FORWARD Nepal, Bharatpur, Chitwan.rk_neupane57@yahoo.co.uk

** Regional Agricultural Research Station, Nepalgunj, NARC
} 
number of varieties and production technologies in different crop commodities, the adoption of those technologies particularly in remote hill districts is far from satisfactory, due to the difficult terrain, transportation problem, poor communication and poor access to seeds and technical know-how among farmers. For increasing crop productivity, quality seed is the cheapest and basic input (Rana, 1997). Seed is not only input but also dynamic instrument for increasing agriculture production (Jha and Rai, 2001). Use of quality seed can increase crop yield up to $15-25 \%$ (DISSPRO, 1999). Farmer participatory evaluation and selection of suitable variety and its spread through farmer networks has been described as the fastest way of variety and seed replacement in areas where seed supply through formal sectors is less than 10 percentages.

The present activities were conducted to help ensure food and nutritional security to the poor farmers of the area through validation, selection, and upscaling of the suitable technologies of cereals and grain legumes in the project area and beyond. Farmer empowerment and promotion of local level seed production system to ensure the timely supply of quality seeds was the second objective of the project being implemented with funding supports from Western Upland Poverty Alleviation Project (WUPAP) and ICRISAT/IFAD. For the study purpose, locally important crops like wheat (Triticum aestivum), maize (Zea maize), fingermillet (Eleusine coroacana), sweet buckwheat (Fagopyrum esculentum Moench), and bitter buckwheat (Fagopyrum tataricum Gaertn.) were selected in consultation with farmers. Some of the potential crops like pigeonpea, field pea (Pisum sativum), and groundnut were also included for testing in subsequent years.

\section{Methodology}

\section{Site description}

Barabish VDC of Bajura district is a remote area now touched by a gravel road and can be reached after 4 hours drive from Sanfebagar of Achham district. This district falls in the category of acute food deficit area, but has the potentials for high production (RARS 2010). Lowland (khet) was the dominant land type (70-75\%) whereas rainfed upland was only 25 $30 \%$ in the villages surveyed. Maize- wheat was the most prevalent cropping pattern followed by maize/millet- fallow in the rainfed uplands. Daily wage earning was an important livelihood option of majority of people in the area. Seasonal migration to nearby India was the next option reported by $30 \%$ of respondents.

\section{Crops and varieties}

The selection of crops was based on the dominant crops grown in the area. Accordingly, wheat, maize, fingermillet, buckwheat were selected for the study. Considering the potential benefits of legumes in enhancing the household nutritional security and maintenance of soil fertility, two legumes pigeonpea were fieldpea, were included in the participatory variety selection (PVS) trials conducted in 4 villages Khuna, Dab, Budheda and Singada of ward No 2 and 4 of Barabish VDC of Bajura district from 2007/08-2009/10. Detailed 
methodology is provided in Annex 1. Crop varieties selected from the PVS and baby trials were included in seed increase programs in the succeeding years with a view to improve access to seeds at the local level. Wherever appropriate, the seeds of farmer preferred varieties were purchased from collaborative farmers from project funds and the seeds were recycled. However, source seed of maize was supplied each year. On-farm seed saving was promoted through on-site coaching on quality seed production and seed storage techniques.

\section{Cereal legume integration}

The remoteness of the area, difficulty in transportation and the soaring price of chemical fertilizers have necessitated the evaluation/ testing of viable alternatives to dependence only on chemical fertilizers for the management of soil fertility/ nutrients needed for successful crop production. Traditionally, farmers cultivate legumes: soybean \& blackgram on paddy bunds. However, there is a great potential of soybean, pigeonpea or groundnut being integrated with maize crop. Therefore, soybean variety Puja, groundnut variety B4, and pigeonpea variety Rampur Rahar-1 was intercropped with local variety of maize in 1:1 ratio in 15 farmer's field at 3 villages in Barabish VDC to help improve total productivity of the hill farming system.

\section{Data collection}

Two local resource persons (LRPs) were hired on daily wage basis for keeping the periodic records and timely communication with research team at RARS Nepalgunj. The LRPs used to help in selection of farmers, trial plots, distribution of trial sets, and help the research team during their visits to project sites. To monitor the trials /activities, team visits to the site were arranged for 6 times a year at an interval of 2 months. Field data were analysed wherever possible through $\mathrm{F}$ test and farmer reactions were collected through interviews and during training and farmers' field days. Yield data from cereal legume intercropping trials were interpreted after converting the intercrop yields into maize equivalent yields through the following formulae:

Maize equivalent yield $=\frac{\text { Yield of inter crops } \mathrm{x} \text { farm gate price of intercrops }}{\text { Farm gate price of maize }}$

\section{Results and discussion}

\section{Participatory variety selection in wheat}

Significant differences $(\mathrm{p} \leq 0.05)$ in days to flower, days to mature, plant height and seed yield were recorded among wheat genotypes (Table 1). The number of days to flower and maturity was the earliest in Annapurna-4, while WK-1204 was significantly late. Annapurna-4 attained the height of $124 \mathrm{~cm}$ and was significantly different from other varieties. Annapurna-3 was the shortest $106 \mathrm{~cm}$ followed by WK-1204 and RR-21. Although RR-21 is de-notified officially, it is still popular among farmers in the remote village and was therefore used a check. Farmers of remote hill district are growing the variety, in spite of its susceptibility to rusts. Farmer express that it is gives some yields even 
under rainfed and late sown conditions. The highest grain yield of $3901 \mathrm{~kg} / \mathrm{ha}$ was obtained from WK-1204 and it was superior to other varieties.

Table 1. Performance of wheat varieties in PVS at Barabish, Bajura, 2007/08

\begin{tabular}{|c|c|c|c|c|}
\hline \multirow{2}{*}{ Variety } & \multicolumn{2}{|c|}{ Days to } & \multirow{2}{*}{$\begin{array}{l}\text { Plant ht } \\
(\mathrm{cm})\end{array}$} & \multirow{2}{*}{$\begin{array}{c}\text { Grain yield } \\
\mathrm{kg} / \mathrm{ha}\end{array}$} \\
\hline & Flower & Mature & & \\
\hline WK- 1204 & $91^{\mathrm{a}}$ & $132^{\mathrm{a}}$ & $110^{c}$ & $3901^{a}$ \\
\hline Annapurna-4 & $81^{\mathrm{b}}$ & $119^{\mathrm{c}}$ & $124^{\mathrm{a}}$ & $2992^{\mathrm{b}}$ \\
\hline Annapurna-3 & $86^{\mathrm{ab}}$ & $129^{\mathrm{b}}$ & $106^{\mathrm{d}}$ & $3001^{\mathrm{b}}$ \\
\hline RR-21 & $80^{\mathrm{b}}$ & $119^{c}$ & $117^{\mathrm{b}}$ & $2630^{\mathrm{b}}$ \\
\hline Mean $(n=5)$ & 84.7 & 125.1 & 114.2 & 3131 \\
\hline$F$-Test & $*$ & $* *$ & $* *$ & $*$ \\
\hline $\mathrm{CV} \%$ & 6.2 & 1.4 & 2.1 & 18.5 \\
\hline$L S D(0.05)$ & 7.3 & 2.4 & 3.3 & 800.0 \\
\hline
\end{tabular}

In a column means followed by the same letters are not significantly different $(p \leq 0.05)$

\section{Participatory variety selection in maize}

Significant difference in grain yield of maize genotypes was recorded in participatory variety selection trials (Table 2). Deuti produced the highest mean seed yield of $3625 \mathrm{~kg} / \mathrm{ha}$ and was superior to all. Arun-1 and Manakamana-1were on par with the local variety in grain yield. Farmers have preferred Deuti due to its bigger sized cobs, taller plants, and higher number of grains per cob and white colour of kernels. In baby trials, Deuti produced the highest mean grain yield of $3568 \mathrm{~kg} / \mathrm{ha}$ and was significantly different from Arun-1 $(2838 \mathrm{~kg} / \mathrm{ha})$, and Manakamana 1 (3014 kg/ha). The results have shown that maize variety Deuti has performed better in terms of cob size, number of cob per plant and uniform filling of cobs and farmers have a strong preference for the white kernels for making breads (Roti).

Table 2. Mean grain yield of maize varieties in PVS \& baby trial at Bajura district in 2007/08

\begin{tabular}{lcc}
\hline Genotype & PVS & Grain yield kg/ha \\
& $2741^{\mathrm{b}}$ & Baby trial \\
\hline Arun-1 & $3625^{\mathrm{a}}$ & $2838^{\mathrm{b}}$ \\
Deuti & $2787^{\mathrm{b}}$ & $3568^{\mathrm{a}}$ \\
Mankamana-1 & $2400^{\mathrm{b}}$ & $3014^{\mathrm{b}}$ \\
Local check. & $2888(n=5)$ & - \\
Mean & $*$ & $3140(n=40)$ \\
F-Test & 18.4 & $*$ \\
CV\% & 734.0 & 6.9 \\
LSD $(0.05)$ & & 253.4 \\
\hline
\end{tabular}

In a column means followed by the same letters are not significantly different $(p \leq 0.05)$ 


\section{Participatory variety selection in fingermillet (Hill set)}

Significant differences in days to $75 \%$ maturity, plant height and seed yield of fingermillet genotypes were recorded in both years (Table 3). The number of days to maturity was the earliest in GE5016, while Kabrekodo-1 (KK-1) was significantly late in and maturity. It attained the mean height of $84 \mathrm{~cm}$ and was significantly different from other varieties. GE5016 was the tallest $88 \mathrm{~cm}$ followed by GE0480 and GE0356. The number of bearing heads $/ \mathrm{m}^{2}$ was counted 44 in GE5016, whereas the number of fingers/head was observed more in genotype GE0356. The highest seed yield of $2459 \mathrm{~kg} / \mathrm{ha}$ in the first year and 2345 $\mathrm{kg} / \mathrm{ha}$ in the second year was obtained from $\mathrm{KK}-1$, the recommended variety for mid-hills. In 2009/10, seed yields of KK-1 were on par with GE5175 (2185 kg/ha). Bajura Local variety was the lowest yielding in both years. In general, genotypes with higher number of heads $/ \mathrm{m}^{2}$ tended to yield higher, although pooled analysis showed non-significant difference in grain yields.

\section{Participatory variety selection in fingermillet (Mountain set)}

Significant differences in days to $75 \%$ maturity, plant height, bearing heads $/ \mathrm{m}^{2}$, number of fingers/head and seed yield were recorded among fingermillet genotypes in both years (Table 4). In 2008/09, the highest yield of $2044 \mathrm{~kg} / \mathrm{ha}$ was obtained from ACC \# 2827-1. This was followed by GE5016 (1936 kg/ha) and GE0059 (1804 kg/ha), which were statistically at par. Local variety was the earliest in maturity, whereas GE5016 took the longest period for maturity (142 days). Plant height ranged between $72-88 \mathrm{~cm}$ and bearing heads $/ \mathrm{m}^{2}$ varied from 26-41 among the genotypes tested. In 2009/10, the highest yield of $1670 \mathrm{~kg} / \mathrm{ha}$ was obtained from NF1703-34 and it was on par with ACC \# 2827-1 and GE5176. The local variety produced the lowest yield in both years (Table 4). Genotypes with higher number of heads $/ \mathrm{m}^{2}$ tended to yield higher, although pooled analysis showed non-significant difference in grain yields. Perusal of data from (Tables $3 \& 4$ ) indicated that GE5016 was adapted to both mountain and midhills environment. 
Agronomy Society of Nepal (ASoN)

Table 3. Mean performance of fingermillet genotypes in PVS Hill- set at Barabish Bajura, 2008/09-2009/10

\begin{tabular}{|c|c|c|c|c|c|c|c|c|c|c|c|c|c|c|c|}
\hline \multirow[b]{2}{*}{ Genotype } & \multicolumn{3}{|c|}{ Days to maturity } & \multicolumn{3}{|c|}{ Plant height $(\mathrm{cm})$} & \multicolumn{3}{|c|}{ No of heads $/ \mathrm{m}^{2}$} & \multicolumn{3}{|c|}{ No of fingers /head } & \multicolumn{3}{|c|}{ Grain yield $(\mathrm{kg} / \mathrm{ha})$} \\
\hline & $\begin{array}{c}\text { Year } \\
1 \\
\end{array}$ & $\begin{array}{c}\text { Year } \\
\text { II }\end{array}$ & Mean & $\begin{array}{c}\text { Year } \\
1\end{array}$ & $\begin{array}{c}\text { Year } \\
\text { I1 }\end{array}$ & Mean & $\begin{array}{c}\text { Year } \\
1 \\
\end{array}$ & $\begin{array}{c}\text { Year } \\
\text { 1I } \\
\end{array}$ & Mean & $\begin{array}{c}\text { Year } \\
1 \\
\end{array}$ & $\begin{array}{c}\text { Year } \\
\text { 1I }\end{array}$ & Mean & $\begin{array}{c}\text { Year } \\
1 \\
\end{array}$ & $\begin{array}{c}\text { Year } \\
\text { 1I }\end{array}$ & Mean \\
\hline GE0480 & 141 & 148 & 144 & 82 & 120 & 101 & 36 & 57 & 46 & 5 & 6 & 5.5 & 1945 & 1100 & 1522 \\
\hline GE5016 & 133 & 128 & 130 & 88 & 118 & 103 & 44 & 45 & 44 & 5 & 5 & 5.0 & 2073 & 1030 & 1551 \\
\hline GE5175 & 137 & 120 & 128 & 72 & 115 & 93 & 42 & 53 & 47 & 5 & 5 & 5.0 & 1680 & 2185 & 1932 \\
\hline GE0356 & 148 & 125 & 136 & 77 & 108 & 92 & 43 & 50 & 46 & 6 & 6 & 6.0 & 1479 & 1730 & 1604 \\
\hline GE0124 & 148 & 115 & 131 & 72 & 116 & 94 & 40 & 45 & 42 & 5 & 6 & 5.5 & 1273 & 1700 & 1486 \\
\hline KK-1 & 142 & 129 & 135 & 69 & 99 & 84 & 34 & 73 & 53 & 5 & 7 & 6.0 & 2459 & 2345 & 2402 \\
\hline Local & 120 & 75 & 97 & 60 & 48 & 54 & 30 & 30 & 30 & 5 & 3 & 4.0 & 1050 & 732 & 891 \\
\hline Mean & 142 & 120 & 129 & 77 & 104 & 90 & 38 & 50 & 44 & 5.1 & 5.42 & 5.3 & 1818.1 & 1546.0 & 1627.2 \\
\hline F-Test & $* *$ & $* *$ & $N s$ & $* *$ & $* *$ & $*$ & $*$ & $* *$ & $*$ & $n s$ & $* *$ & $n s$ & $* *$ & $* *$ & $n s$ \\
\hline$C V \%$ & 1.43 & 15.31 & 9.47 & 2.06 & 11.79 & 15.2 & 4.6 & 3.36 & 22.03 & 12.5 & 13.93 & 16.77 & 12.97 & 12.61 & 26.50 \\
\hline $\begin{array}{l}L S D \\
(0.05)\end{array}$ & 3.69 & 27.40 & 16.01 & 2.88 & 17.7 & 17.66 & 6.50 & 6.25 & 12.80 & 1.12 & 1.123 & 1.159 & 429.0 & 331.2 & 564.0 \\
\hline
\end{tabular}


Agronomy Journal of Nepal (Agron JN) Vol. 2: 2011

Table 4. Mean performance of fingermillet genotypes in PVS Mountain set at Barabish Bajura, 2008/09-2009/10

\begin{tabular}{lcccccccccccccccc}
\hline \multirow{2}{*}{ Genotype } & \multicolumn{3}{c}{ Days to maturity } & \multicolumn{3}{c}{ Plant height $(\mathrm{cm})$} & \multicolumn{3}{c}{ No of heads/m } & \multicolumn{4}{c}{ No of fingers /head } \\
& Year I & Year II & Mean & Year I & Year II & Mean & Year I & Year II & Mean & Year I & Year II & Mean & Year I & Year II & Mean \\
\hline GE5176 & 142 & 129 & 135 & 73 & 118 & 95 & 35 & 37 & 36 & 5 & 6 & 5.5 & 1685 & 1585 & 1635 \\
GE5016 & 140 & 142 & 141 & 88 & 107 & 97 & 41 & 41 & 41 & 5 & 5 & 5.0 & 1936 & 1045 & 1490 \\
ACC \# 2827-1 & 139 & 119 & 129 & 84 & 113 & 98 & 34 & 52 & 43 & 5 & 5 & 5.0 & 2044 & 1612 & 1828 \\
GE0059 & 131 & 118 & 124 & 79 & 112 & 95 & 26 & 42 & 34 & 4 & 5 & 4.5 & 1804 & 775 & 1289 \\
GE0018 & 128 & 115 & 121 & 75 & 125 & 100 & 34 & 32 & 33 & 5 & 5 & 5.0 & 1472 & 1295 & 1383 \\
NE1703-34 & 124 & 113 & 118 & 72 & 109 & 90 & 31 & 49 & 40 & 5 & 6 & 5.5 & 1528 & 1670 & 1599 \\
Local & 118 & 75 & 96 & 76 & 48 & 62 & 28 & 30 & 29 & 4 & 3 & 3.5 & 1361 & 732 & 1046 \\
Mean & 132 & 116 & 124 & 78 & 105 & 91 & 33 & 40 & 37 & 4.7 & 5.0 & 4.86 & 1690 & 1245 & 1467 \\
F Test & $* *$ & $*$ & $*$ & $* *$ & $* *$ & $*$ & $*$ & $*$ & $n s$ & $*$ & $* *$ & $*$ & $*$ & $* *$ & $n s$ \\
CV \% & 1.98 & 15.90 & 7.81 & 2.61 & 11.41 & 20.18 & 8.88 & 4.6 & 17.64 & 7.71 & 15.12 & 11.0 & 13.56 & 17.91 & 20.72 \\
LSD (0.05) & 4.63 & 27.28 & 12.64 & 3.62 & 18.16 & 24.12 & 5.15 & 12.52 & 8.4 & 0.653 & 1.123 & 0.699 & 407.9 & 289.7 & 397.7 \\
\hline
\end{tabular}




\section{Participatory variety selection in buckwheat}

Significant differences to $50 \%$ flower \& $75 \%$ maturity and grain yield were recorded among sweet buckwheat genotypes (Table 5). The highest mean grain yield of $1625 \mathrm{~kg} / \mathrm{ha}$ was obtained from IR-13. And it was on par with GF5289 and GF5089. The local genotype was the lowest yielder and the earliest in flowering (65 days) and maturity (104 days), whereas ACC \# -2244 took the longest period for maturity (117 days). In bitter buckwheat, significant differences for grain yield, days to $50 \%$ flowering and $75 \%$ maturity were recorded amongst genotypes (Table 6). Grain production was recorded the highest in genotype ACC \#- 2223-1 (4813 kg/ha), which was followed by Sample \# 8 (2333 kg/ha) and ACC \# -2227-1 (1354 kg/ha) and those were statically on par. Days to flowering and maturity vary from 76-98 and 116-135 days, respectively. The yield levels of bitter buckwheat were higher than those of sweet (Table $5 \& 6$ ). The higher yield levels of bitter buckwheat in mid hills due to self pollinating nature of the crop have been reported by Bania (1990).

Table 5. Performance of sweet buckwheat genotypes in PVS, Barabish Bajura 2008/09

\begin{tabular}{lccc}
\hline Genotype & $\begin{array}{c}\mathbf{5 0 \%} \text { flowering } \\
\text { days }\end{array}$ & $\begin{array}{c}\mathbf{7 5 \%} \text { maturity } \\
\text { days }\end{array}$ & $\begin{array}{c}\text { Grain yield } \\
\text { (kg/ha) }\end{array}$ \\
\hline GF5289 & $74^{\text {abc }}$ & $114^{\mathrm{a}}$ & $1375^{\mathrm{a}}$ \\
GF5089 & $67^{\mathrm{d}}$ & $115^{\mathrm{a}}$ & $1375^{\mathrm{a}}$ \\
GF5274 & $68^{\mathrm{c}}$ & $115^{\mathrm{a}}$ & $917^{\mathrm{c}}$ \\
ACC \#-2244 & $71^{\mathrm{bd}}$ & $117^{\mathrm{a}}$ & $1000^{\mathrm{c}}$ \\
GF5063 & $80^{\mathrm{a}}$ & $113^{\mathrm{a}}$ & $875^{\mathrm{c}}$ \\
IR-13 & $77^{\mathrm{ab}}$ & $112^{\mathrm{a}}$ & $1625^{\mathrm{a}}$ \\
Local (sweet) & $65^{\mathrm{d}}$ & $104^{\mathrm{b}}$ & $750^{\mathrm{c}}$ \\
Mean & 72 & 113 & 1131 \\
F-Test & $*$ & $*$ & $* *$ \\
CV\% & 5.99 & 3.42 & 19.21 \\
LSD $(0.05)$ & 6.39 & 5.74 & 322.7 \\
\hline
\end{tabular}

In a column means followed by the same letters are not significantly different $(\mathrm{p} \leq 0.05)$

Table 6. Performance of bitter buckwheat genotypes in PVS, Bajura 2008/09

\begin{tabular}{lccc}
\hline \multicolumn{1}{c}{ Genotype } & $\mathbf{5 0 \%}$ Flowering & $\mathbf{7 5 \%}$ Maturity & Grain yield (kg/ha) \\
\hline ACC \# -2227-1 & $87^{\mathrm{c}}$ & $121^{\mathrm{c}}$ & $1354^{\mathrm{bc}}$ \\
ACC \#- 2223 & $87^{\mathrm{c}}$ & $125^{\mathrm{bc}}$ & $812^{\mathrm{c}}$ \\
MY-2-27-1 & $77^{\mathrm{d}}$ & $121^{\mathrm{c}}$ & $917^{\mathrm{c}}$ \\
Sample \# 8 & $92^{\mathrm{b}}$ & $128^{\mathrm{b}}$ & $2333^{\mathrm{b}}$ \\
ACC \#- 2223-1 & $98^{\mathrm{a}}$ & $135^{\mathrm{a}}$ & $4813^{\mathrm{a}}$ \\
\hline
\end{tabular}




\begin{tabular}{lccc}
\hline \multicolumn{1}{c}{ Genotype } & $\mathbf{5 0 \%}$ Flowering & $\mathbf{7 5 \%}$ Maturity & Grain yield (kg/ha) \\
\hline Kavre Bitter buckwheat & $86^{\mathrm{c}}$ & $123^{\mathrm{c}}$ & $604^{\mathrm{c}}$ \\
Local (Bitter) & $76^{\mathrm{d}}$ & $116^{\mathrm{d}}$ & $396^{\mathrm{d}}$ \\
Mean & 86 & 124 & 1523 \\
F-Test & $* *$ & $* *$ & $* *$ \\
CV\% & 2.59 & 2.38 & 38.13 \\
LSD $(0.05)$ & 3.31 & 4.39 & 862.7 \\
\hline
\end{tabular}

In a column means followed by the same letters are not significantly different $(\mathrm{p} \leq 0.05)$

\section{Participatory variety selection in fieldpea}

Fieldpea is a leguminous crop which possesses inherent ability to fix atmospheric nitrogen in the soil through symbiotic bacteria and improves the soil health for future. It is also a major source of protein needed by the human body in regular activities. Fieldpea is used as a curry, roasted grain and sold as a green pods for numerous food purposes. Farmers in the project area, grow a local fieldpea variety with small grain size and low productivity potentialities. Therefore, varieties with high production potential were introduced through PVS trial at Dab, Khuna, Singada, and Badeda villages of Barabish VDC.

Significant difference in grain yield and maturity days of fieldpea varieties was recorded in participatory variety selection trials (Table 7). Kalaam Local was the earliest maturing variety and it was on par with Arkel. Sikkime took the highest number of days to mature. Variety Sikkime produced the highest mean green pod yield of $4185 \mathrm{~kg} / \mathrm{ha}$, whereas Kalaam local produced only $2190 \mathrm{~kg} / \mathrm{ha}$. Farmers have expressed that Sikkime and Arkel both are promising in the area and they would expand the area under those varieties as mixed crop with wheat.

Table 7. Performance of fieldpea genotypes in PVS at Bajura district in 2008/09

\begin{tabular}{lccl}
\hline Variety & Maturity days & Fresh pod yield (kg/ha) & \multicolumn{1}{c}{ Farmers' reaction } \\
\hline Sikkime & $191^{\mathrm{a}}$ & $4185^{\mathrm{a}}$ & $\begin{array}{l}\text { Bold and smooth seed surface, high } \\
\text { production potential but late. }\end{array}$ \\
Arkel & $179^{\mathrm{ab}}$ & $3624^{\mathrm{b}}$ & $\begin{array}{l}\text { Early maturing type, suitable for } \\
\text { vegetable purpose. }\end{array}$ \\
Kalaam Local & $171^{\mathrm{b}}$ & $2190^{\mathrm{c}}$ & $\begin{array}{l}\text { Early, small grain size, less } \\
\text { production potential. }\end{array}$ \\
Mean & 180 & 3333 & \\
F-Test & $*$ & $*$ & \\
CV \% & 6.68 & 24.31 & \\
LSD $(0.05)$ & 12.94 & 868.8 & \\
\hline
\end{tabular}

In a column means followed by the same letters are not significantly different $(\mathrm{p} \leq 0.05)$ 


\section{Mixed cropping of legumes}

The highest intercrop yield was obtained from groundnut $(0.87 \mathrm{t} / \mathrm{ha})$, followed by pigeonpea $(0.73 \mathrm{t} / \mathrm{ha})$ and soybean $(0.26 \mathrm{t} / \mathrm{ha})$. Combined grain yields were similar under groundnut or pigeonpea intercropped with maize (Table 8). When intercrop legume yields were converted to maize equivalent yield on the basis of prevailing market price of individual commodities, the highest maize equivalent was obtained from maize + groundnut $(2.32 \mathrm{t} / \mathrm{ha})$, followed by maize + pigeonpea $(1.71 \mathrm{t} / \mathrm{ha})$. The total maize equivalent yield from the system was 3.35 $\mathrm{t} /$ ha for maize + groundnut and 2.80 for maize + pigeonpea. .Farmers in the project site have expressed their interest in expanding the cultivation of pigeonpea variety Rampur Rahar-1 and testing other earlier maturing varieties to allow timely sowing of wheat in the rainfed uplands.

Table 8. Mean seed yield ( $t /$ ha) of grain legumes intercropped with maize, Barabish Bajura 2008/09

\begin{tabular}{lccccc}
\hline \multicolumn{1}{c}{ Treatment } & $\begin{array}{c}\text { Legume } \\
\text { yield } \\
\text { (t/ha) }\end{array}$ & $\begin{array}{c}\text { Maize } \\
\text { yield } \\
\text { (t/ha) }\end{array}$ & $\begin{array}{c}\text { Combined } \\
\text { yield } \\
\text { (t/ha) }\end{array}$ & $\begin{array}{c}\text { Maize equivalent } \\
\text { yield from } \\
\text { legumes (t/ha) }\end{array}$ & $\begin{array}{c}\text { Total Maize } \\
\text { equivalent } \\
\text { yield (t/ha) }\end{array}$ \\
\hline $\begin{array}{l}\text { Maize }+ \\
\text { Soybean }\end{array}$ & $\mathrm{A}$ & $\mathrm{B}$ & $\mathrm{A}+\mathrm{B}$ & $\mathrm{D}$ & $\mathrm{B}+\mathrm{D}$ \\
$\begin{array}{l}\text { Maize }+ \\
\text { Groundnut }\end{array}$ & 0.26 & 1.18 & 1.36 & 0.39 & 1.57 \\
$\begin{array}{l}\text { Maize }+ \\
\text { Pigeonpea }\end{array}$ & 0.87 & 1.06 & 1.93 & 2.32 & 3.35 \\
Mean $(n=15)$ & 0.73 & 1.09 & 1.91 & 1.71 & 2.80 \\
& 0.62 & 1.11 & 1.73 & 1.47 & 2.58 \\
\hline
\end{tabular}

Note: Farm gate price of soybean NRs 22, groundnut 40, pigeonpea $35 \&$ maize 15 per kg used for calculation of Maize Equivalent yield from intercrop legume yield.

\section{Introduction of pigeonpea at Barabish, Bajura}

Medium duration pigeonpea varieties Rampur Rahar-1 was introduced and evaluated in terrace risers and sloppy areas at Barabish VDC. The results obtained so far have indicated vigorous growth of variety Rampur Rahar-1 in farmers' field. Preliminary results showed seed yields of upto $1500 \mathrm{~kg} / \mathrm{ha}$ from the variety (Table 9). However, the variety would not vacate the field for sowing wheat. Therefore, new extra early variety ICPL88039 was introduced in 2009/10 season. The mean yield of ICPL88039 from 29 fields was 1152 $\mathrm{kg} / \mathrm{ha}$. 
Table 9. Performance of pigeonpea varieties at Barabish VDC of Bajura district

\begin{tabular}{cllcccl}
\hline Year & Villages & Variety & $\begin{array}{c}\text { No of } \\
\text { HHs }\end{array}$ & $\begin{array}{c}\text { Mean yield } \\
\text { kg/ha }\end{array}$ & $\begin{array}{c}\text { Yield range } \\
\text { kg/ha }\end{array}$ & Remarks \\
\hline $2008 / 09$ & $\begin{array}{l}\text { Khuna \& } \\
\text { Singada }\end{array}$ & $\begin{array}{l}\text { Rampur } \\
\text { Rahar 1 }\end{array}$ & 15 & 434 & $250-1500$ & $\begin{array}{l}\text { Seeds saved by farmers } \\
\text { for next year }\end{array}$ \\
$2009 / 10$ & $\begin{array}{l}\text { Singada } \\
\text { Khuna }\end{array}$ & ICPL88039 & 29 & 1152 & $300-2500$ & $\begin{array}{l}\text { F to F seed dissemination } \\
\text { of seeds to other districts } \\
\text { reported }\end{array}$ \\
\hline
\end{tabular}

\section{Upscaling farmer selected crop varieties}

In efforts to strengthen the local seed systems, we incorporated selection, production and storage of seeds in the farmer training program. While farmer to farmer ( $f$ to $f$ ) diffusion of seeds of selected varieties would play vital roles in the remote hill districts, the institutionalization of seed increase program through involvement of seed entrepreneurs is equally important. The district as a whole is a food deficit area, and farmers need cash just after crop harvest for meeting the expenses incurred in production of different crops. To ensure that farmers will not consume or sale seeds of varieties selected from PVS for consumption, intensive interaction/group discussion was organized. They were asked to save and sow the seeds for the next season.

The upscaling of promising farmer selected crop varieties in the project sites was initiated through distribution of wheat variety WK-1204 to nine farmers in 2007/08 winter and we were able to collect $139 \mathrm{~kg}$ seeds after harvest and the seeds were kept in the safe custody of local farmer leader. Farmers were motivated in saving seeds of promising PVS varieties through purchase of seeds by the project in the first year. Following this experience, we involved 248 households in upscaling of selected varieties of wheat, maize, pigeonpea,

Table 10. Upscaling cereals and legumes at Barabish VDC, Bajura

\begin{tabular}{llccccc}
\hline Crop & Variety & $\begin{array}{c}\text { No of } \\
\text { HH }\end{array}$ & $\begin{array}{c}\text { Area per } \\
\text { HH M }\end{array}$ & $\begin{array}{c}\text { Total seed } \\
\text { production } \\
\text { (kg) }\end{array}$ & $\begin{array}{c}\text { Mean } \\
\text { yield } \\
\text { (kg/ha) }\end{array}$ & $\begin{array}{c}\text { Yield range } \\
\text { (kg/ha) }\end{array}$ \\
\hline Pigeonpea 2009/10 & ICPL88039 & 29 & 100 & 288 & 1152 & $300-2500$ \\
Buckwheat 2009/10 & IR-13 & 16 & 250 & 157 & 1609 & $1182-2222$ \\
Maize 2009/10 & Arun -1 & 65 & 250 & 2155 & 1113 & $200-3500$ \\
Finger millet 2009/10 & Okhle-1 & 67 & 250 & 2014 & 926 & $320-2400$ \\
Wheat 2007/08 & WK-1204 & 9 & 250 & 139 & $\begin{array}{c}\text { Seed } \\
\text { collected }\end{array}$ & - \\
Wheat 2008/09 & WK-1204 & 52 & 250 & 1697 & - & - \\
Total & & 238 & - & 6450 & - & - \\
\hline
\end{tabular}


buckwheat and fingermillet in the project village from 2007/08 to 2009/10 that resulted in production of $6450 \mathrm{~kg}$ seeds (Table 10). This has significantly contributed to the local level seed and food security. During interaction with farmers, it was revealed that 30 percent of the produce was used for seed purpose for own use or for sell to others. The initial impact of increased seed production of PVS varieties is that in the local hotels, the rota (bread) being made is all from wheat variety WK-1204.

\section{Conclusion}

Due to poor access of improved varieties, farmers are still growing low yielding local varieties or old outdated varieties of crops in the remote hill district. Farmer participatory trials have provided opportunity for farmers to choose suitable varieties for a particular locality. The results have clearly indicated high yielding potential of recommended varieties. The selected wheat variety WK-1204 and maize Deuti Arun -1 should be scaled up widely in collaboration with local extension offices and NGOs/CBOs. In maize, white kernel and early maturity traits is farmer's preference. Recommended varieties of fingermillet were better than the local variety in grain yield and therefore should be promoted. Promising variety GE5016 and GE5175 should be further tested and scaled up in mid hills. For high hills, ACC \# 2827-1 and NF1703-34 need further validation and up scaling. Buckwheat genotype IR13 preferred by farmers should be promoted widely. Field pea variety Sikkime should be promoted. Maize + groundnut intercropping was found profitable than maize + pigeonpea or maize + soybean, due to high total combined yields and higher price of groundnut. Extra short-duration variety of pigeonpea ICPL88039 should be widely disseminated in pigeonpea-wheat system or in terrace risers. Pigeonpea variety RR-1 needs promotion in maize + pigeonpea system where the field remains fallow after summer maize in hills. On-the-spot trainings of farmers were very effective in convincing them of the potential benefits of participatory research and development activities. Training on seed production and storage methods should be given top priority in future program/ activities.

\section{Acknowledgements}

The cooperation received from collaborative farmers, social mobilizes from WUPAP, DADO staff Bajura, and support staff during the conduct of field activities at the project site is duly acknowledged. NORP, NGLRP, HCRP Kavre, Agri Botany Div Khumaltar receive due appreciation for their participation in farmer orientation training activities and supply of seed materials of respective commodities. We express our gratitude WUPAP and ICRISAT for providing timely suggestions and budget for the conduct of activities and to NARC management for approval to implement the activities. 


\section{References}

Bania, BK. 1990. Buckwheat in Nepal. Paper presented at the 4th International Symposium on Buckwheat, Orel, USSR, July 10-15, 1989.

Dahal, H and DR Khanal. 2010. Food security and climate change adaptation framework: issues and challenges. MOAC home page.

District Level Seed Self Sufficiency Programme (DISSPRO). 1999. A Guideline. 1999. His Majesty's Government, Ministry of Agriculture and Co-operatives, DOA, Crop Development Division, Hariharbhawan, Lalitpur. 19p.

Jha, N and A Rai. 2001. Approaches of AIC on ensuring cereal seed supplies. Proceeding of third National Seed Seminar, August 13-14, Kathmandu, Nepal. pp.139-151.

Neupane RK, BP Mahato, R Darai and B Hamal. 2008. Annual Technical Report on RARS Nepalgunj Implemented Western Upland Poverty Alleviation Project Activities at Bajura. RARS Nepalgunj.

Neupane, RK, BP Mahato, R Darai and B Hamal. 2009. Annual Technical Report. On RARS Nepalgunj Implemented Western Upland Poverty Alleviation Project Activities at Bajura.

Rana, DS. 1997. Guidelines for Seed Quality Control and Minimum Seed Certification Standards. HMG/FAO.

RARS (Regional Agricultural Research Station), Nepalgunj. 2010. Annual Progress Report ICRISAT IFAD-954 ICRISAT - Jan-Dec 2009. RARS Khajura, Nepalgunj.

Annex 1. Details of activities implemented at Barabish VDC of Bajura district during 2007/08 to 2009/10

\begin{tabular}{|c|c|c|c|c|c|c|c|}
\hline Crop & Activities & Year & HH & Varieties & $\begin{array}{c}\text { Plot size } \\
\mathbf{M}^{2} \\
\end{array}$ & Fertilizer & Management \\
\hline \multirow{2}{*}{ Wheat } & PVS & $2007 / 08$ & 5 & 5 & 15 & \multirow[t]{3}{*}{ Recom } & Irrigated \\
\hline & Baby & $2007 / 08$ & 25 & 4 & 250 & & Irrigated \\
\hline \multirow{2}{*}{ Maize } & PVS & $2007 / 08$ & 5 & 4 & 15 & & Rainfed \\
\hline & Baby & $2007 / 08$ & 40 & 3 & 250 & Recom & Rainfed \\
\hline \multirow{2}{*}{ Fingermillet } & PVS Hill & $\begin{array}{l}2008 / 09 \& \\
2009 / 10\end{array}$ & 3 & 7 & 6 & \multirow{2}{*}{$\begin{array}{l}\text { Farmers' } \\
\text { practice }\end{array}$} & \multirow{2}{*}{ Rainfed } \\
\hline & PVS Mountain & $\begin{array}{l}2008 / 09 \& \\
2009 / 10\end{array}$ & 5 & 7 & 6 & & \\
\hline Buckwheat & $\begin{array}{l}\text { PVS Sweet and } \\
\text { bitter }\end{array}$ & $2008 / 09$ & 5 & 7 & 6 & $\begin{array}{l}\text { Farmers' } \\
\text { practice }\end{array}$ & Rainfed \\
\hline $\begin{array}{l}\text { Maize, soybean, } \\
\text { pigeonpea \& } \\
\text { groundnut }\end{array}$ & $\begin{array}{l}\text { Cereal legume } \\
\text { intercropping }\end{array}$ & 2008/09 & 15 & 3 & 15 & & \multirow{4}{*}{ Rainfed } \\
\hline \multirow{2}{*}{ Pigeonpea } & PVS Medium & $2008 / 09$ & 50 & 2 & 150 & \multirow{4}{*}{$\begin{array}{l}\text { Farmers' } \\
\text { Practice }\end{array}$} & \\
\hline & PVS Extra short & $2009 / 10$ & 29 & 1 & 100 & & \\
\hline Fieldpea & PVS & 2008/09 & 12 & 3 & 15 & & \\
\hline $\begin{array}{l}\text { Upscaling Seed } \\
\text { increase }\end{array}$ & Different crops & $2007-2010$ & 238 & - & $\begin{array}{l}6450 \mathrm{~kg} \\
\text { total } \\
\text { production }\end{array}$ & & $\begin{array}{l}\text { Rainfed } \\
\text { /Irrigated }\end{array}$ \\
\hline
\end{tabular}

